\title{
ANATOMI TUMBUHAN OBAT: CIPLUKAN (Physalis angulata)
}

\section{Anatomy of Medicinal Plant : Physalis angulata}

\author{
Vlorensius $^{\mathrm{a}^{*}}$ \\ a Jurusan Pendidikan Biologi, Universitas Borneo Tarakan, Tarakan, Kalimantan Utara, Indonesia \\ *Corresponding author: J1. Amal Lama, Tarakan Timur, Tarakan, Kalimantan Utara, 77123, Indonesia. E-mail: vlodit72@ymail.com
}

\begin{abstract}
Abstrak
Pyhsalis angulata merupakan family Solanaceae. Masyarakat umum mengetahui tumbuhan tersebut sebagai obat. Tumbuhan sebagai obat umumnya memproduksi senyawa obat yang disimpan dalam struktur khusus, sehingga penelitian ini bertujuan untuk mengamati anatomi $P$. angulata untuk menemukan struktur khusus yang diduga menyimpan senyawa obat. Pengamatan anatomi menggunakan mikroskop dan pewarnaan safranin. Berdasarkan pengamatan, jaringan yang dijumpai yaitu jaringan yang paling umum seperti jaringan epidermis, jaringan dasar, jaringan penguat (Kolenkim dan sklerenkim) dan jaringan pengangkut. Struktur khusus berupa trikoma dijumpai di daun. Struktur tersebut diduga memproduksi senyawa sebagai bahan obat.
\end{abstract}

\section{Kata kunci}

Anatomi, Obat, Pyhsalis angulata

\begin{abstract}
Pyhsalis angulata is a family of Solanaceae. Most of the general public knows these plants as medicine. Plants as medicines generally produce of medicinal compounds that have been stored in special structures. So this study was aimed to observe the anatomy of the P. angulata to find specific structures that are suspected of storing medicinal compounds. Anatomical observations using microscope and safranin staining. Based on the observation, the most common tissuethat have been found epidermal tissue, basic tissue, reinforcing tissue (collenchyma and sclerenkim), and vascular bundle. Furthermore,A special structure in the form of a trichome were found in the leaf. It is suspected to produce of drug compounds.
\end{abstract}

\section{Keywords}

Anatomy, Medicine, Pyhsalis angulata

\section{Pendahuluan}

Famili Solanaceae merupakan famili terung-terungan yang memiliki nilai ekonomi yang sangat penting bagi kehidupan manusia. Selain itu, famili tersebut banyak dijumpai disekitar pekarangan rumah sehingga sangat mudah didapatkan oleh masyarakat. Berbagai spesies dalam famili Solanaceae dapat digunakan sebagai sumber makanan dan obat-obatan. 


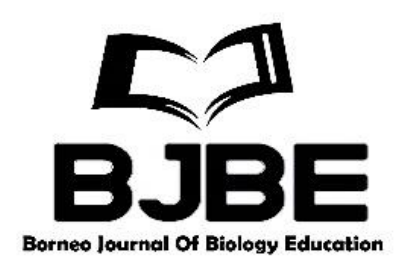

Sepesies dalam famili Solanaceae yang dapat digunakan sebagai obat misalnya Lycopersicon esculentum Mill., Physalis peruviana L. (Namukobe et al. 2011), Solanum americanum (Shahet al. 2013), dan Phsyalis angulata L. (Rupaet al. 2017).

Spesies dari famili Solanaceae memiliki alat perlindungan dari predator berupa rambutrambut yang disebut dengan trikoma yang umumnyaterdapat pada bagian luar batang dan daun. Rambut-rambut tersebut umumnya berupa trikoma kelenjar karena menyimpan senyawa seperti terpenoid ((Rupaet al. 2017). Kajian ilmiah mengenai struktur anatomi tumbuhan obat seperti Phsyalis angulata L. sangat perlu dilakukan. Hal tersebut dapat membantu dalam pelacakan struktur khusus yang berpotensi sebagai penyimpanan senyawa kimia yang dapat dimanfaatkan sebagai bahan obat.Sehingga penelitian ini bertujuan untuk mengetahui struktur anatomi tanaman Phsyalis angulata L.

\section{Material dan metode}

\section{Persiapan Sampel}

Tumbuhan P.angulataL. diambil di kota Tarakan melalui teknik purposive sampling.Pengamatan struktur anatomi dilakukan dalam laboratorium dasar di Jurusan Pendidikan Biologi, Fakultas Keguruan dan Ilmu Pendidikan.

\section{Pengamatan struktur anatomi}

Sampelyang segar berupa organ akar, batang dan daun dibawa ke laboratorium untuk dibuat dalam bentuk sediaan mikroskopissemi permanen mengikuti metode sediaan utuh (Sass 1951). Sampel yang masih segar disayat secara membujur dan melintang. Selanjutnya hasil sayatan tersebut dicelupkan dibaiclyn, setelah itu dibilas denga air sebanyak tiga kali kemudian di letakkan di kaca objek dan ditetesi dengan larutan gliserin kemudian ditutup menggunakan cover glass. Selanjutnya,anatomi (bentuk dan struktur jaringan) sampel diamati dengan menggunakan mikroskop (Olympus CX21). Struktur anatomi sampeldivisualisasikan melalui optilab advance 2010.

\section{HasildanDiskusi}

Struktur anatomi akar, batang dan daun $P$. angulata tersusun dari berbagai macam sel dan jaringan. Organ akar tersusun dari jaringan epidermis, korteks, dan jaringan vaskular (gambar 1). Organ batang tersusun jaringan epidermis, jaringan dasar, jaringan penguat (kolenkim dan sklerenkim), dan jaringan pengangkut (gambar 2). Sklerenkim dijumpai di bagian korteks dan di antara jaringan pengangkut. Daun tersusun dari jaringan epidermis, palisade, dan bunga karang. Di epidermis terdapat stomata dan jenis trikoma berupa kapitata. Trikoma kapitata dijumpai di bagian bawah (abaksial) dan bagian atas (adaksial) daun. Trikoma kapitata mempunyai tangkai dan kepala yang berisiempat sel. Selain itu terdapat sel idioblas yang berisi kristal druss. Sel idioblas tersebut berada di jaringan bunga karang (gambar 3). 

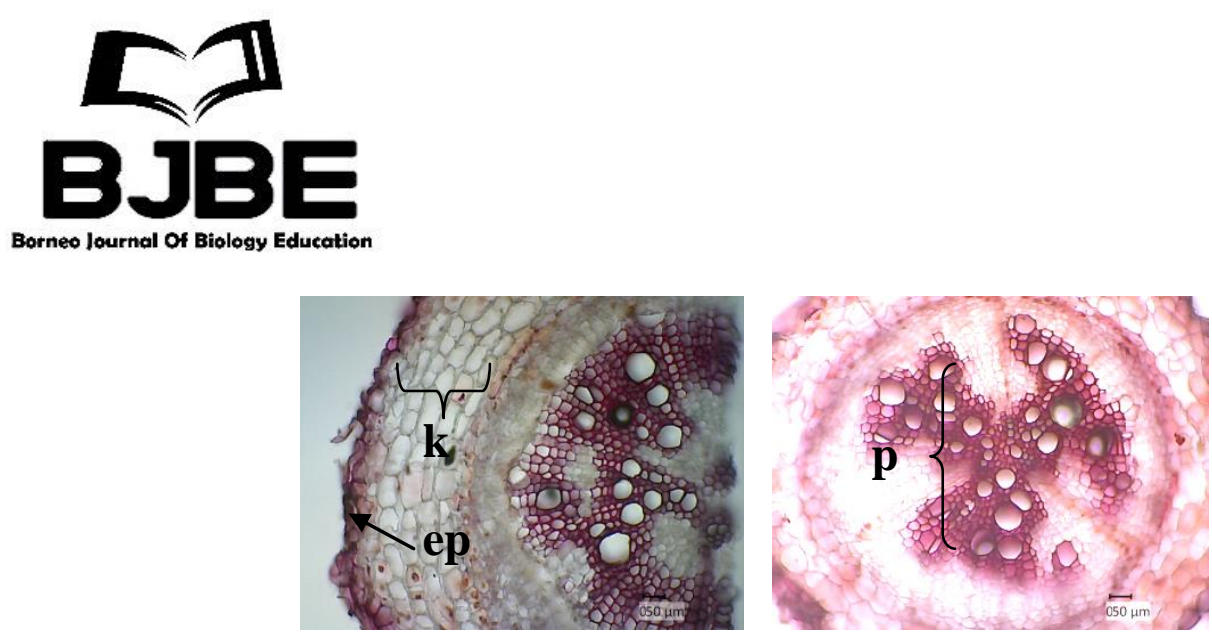

Gambar1. Sayatan melintang akar P. angulata. Ep: epidermis, p: pengangkut, dan k: korteks. Bar 50 $\mu \mathrm{m}$.
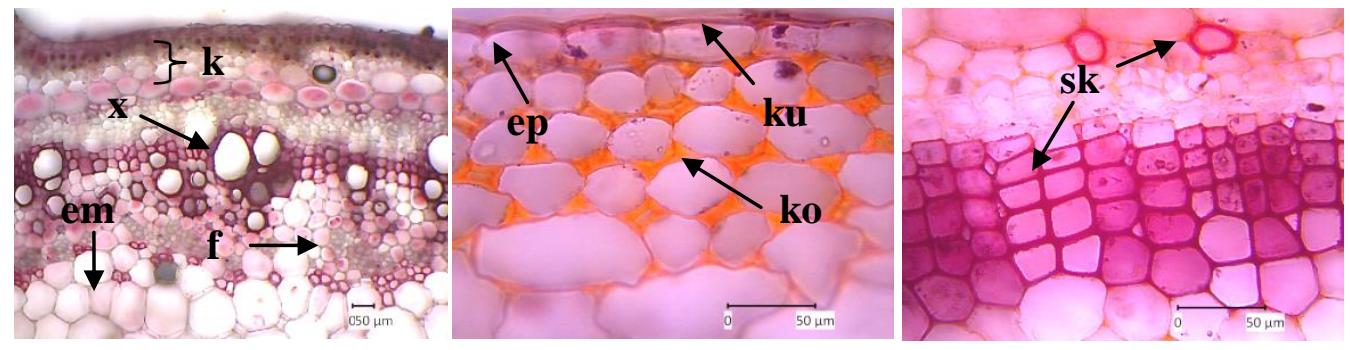

Gambar 2. Sayatan melintang batang $P$. angulata.ep: epidermis, k: korteks, em: empulur, ko: kolenkim, sk: sklerenkim, ku: kutikula, x: xilem, dan f; floem. Bar 50 $\mu \mathrm{m}$.
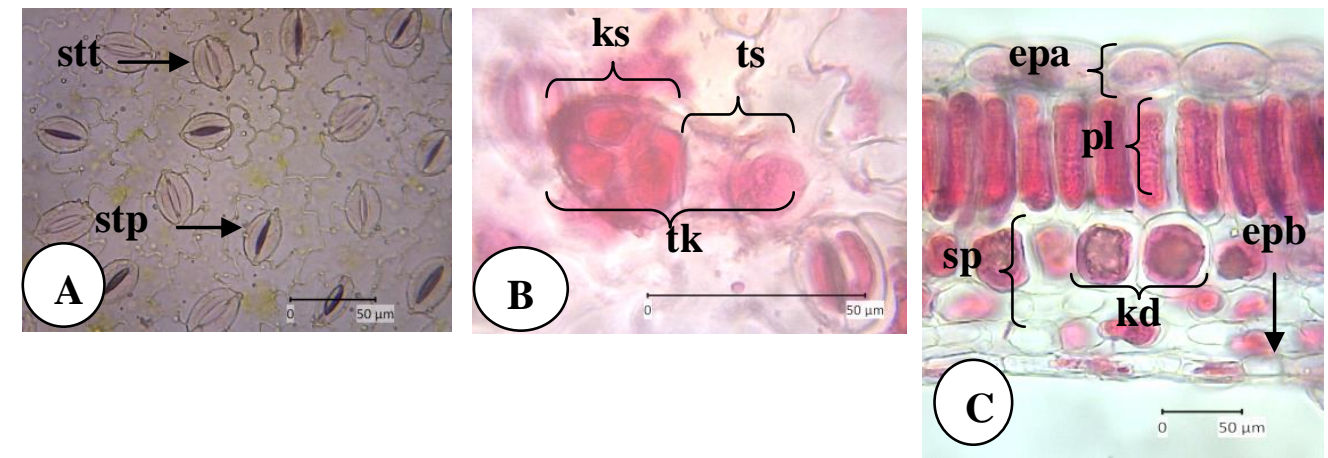

Gambar3. Anatomi daun P. angulatasayatan paradermal (A dan B) sayatan melintang (C). epa: epidermis atas, epb: epidermis bawah, pl: palisade, sp: spons, kd: kristal, stt: stomata terbuka,stp: stomata tertutup, tk: trikoma kapitat, ks: kepala sel, dan ts; tangkai sel. Bar $50 \mu \mathrm{m}$.

Derivat jaringan epidermis yang dijumpai yaitu berupa stomata dan trikoma (Gambar 3). Trikoma tersebut merupakan tipe kapitat. Menurut Rupaet al. (2017), trikoma kapitata pada $P$. angulata memiliki satu sel tangkai dan empat sel kepala yang mengandung senyawa lipofil, terpenoid dan alkaloid. Pada tanaman Withania somnifera (L.) Dunal yang termasuk dalam familiSolanaceaememiliki trikoma non-kelenjar dan kelenjar kapitat yang mengandung senyawa fenol dan alkaloid (Munien et al. 2015). Selain itu, trikoma kelenjar berupa kapitata dijumpai pada famili lain misalnya famili Lamiaceae. Spesies yang termasuk dalam famili tersebut yaitu Hyptis capitata Jacq. (Rupaet al. 2017). 


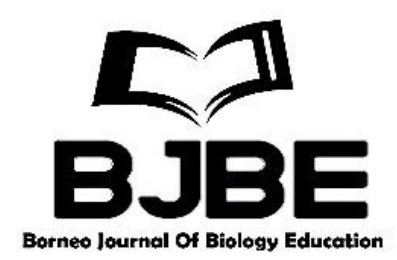

Struktur sekretori berupa trikoma umumnya dapat dijumpaidi bagian daun dan batang tumbuhan misalnya tipe peltat dijumpai pada daun Piper porphylophyllumdan Piperungaramense C. DC mengandung senyawa alkaloid, terpenoid serta lipofil (Suparmanet al. 2018) dan pada kulit batang Peronema canescens Jack (Rupa, 2015). Selain trikoma, struktur sekretori berupa sel idioblas dijumpai di daun $P$. angulata. Sel tersebut megandung krital druss. Berbaga macam senyawa yang terkandung dalam sel idioblas, misalnya senyawa lipofil dalam sel idioblas H. capitata(Rupaet al. 2017), Polyalthia rumphii, Decaspermum fruticosum (Umah et al. 2017) dan terpenoid dalam sel idioblas D. Fruticosum (Umah et al. 2017). Selain keragaman kandungan senyawa, sel idioblas juga memiliki bentuk dan ukuran yang beragammisalnya pada tanaman $P$. paniculata $L$. berbentuk bulat memiliki panjang $25.20 \mu \mathrm{m}-42.19 \mu \mathrm{m}$, lebar $22.63 \mu \mathrm{m}-53.68 \mu \mathrm{m}$ dan sel idioblas bentuk panjang memiliki ukuran panjang $44.02 \mu \mathrm{m}-80.96 \mu \mathrm{m}$, lebar $28.03 \mu \mathrm{m}$ - $48.22 \mu \mathrm{m}$ (Salurapa, 2018).

Sel idioblas umumnya dapat dijumpai di seluruh bagian tumbuhan yang tersebar diberbagai jaringan tumbuhan misalnya pada epidermis daun Physialis angulata (Rupaet al. 2017), akarPolygala paniculata L. (Salurapa, 2018), batangbatangC. specious Koenig J.E Smith.(Suparman, 2018), dan umbi Eleutherine palmifolia(L.) Merr. (Allobua, 2018), jaringan palisade Catharanthus roseus (St-Pierreet al. 1999), dan korteks Cissus verticillata (de Oliveiraet al.2012).

\section{Kesimpulan}

Struktur anatomi $P$. angulata terdiri dari jaringan yang umum dijumpai yaitu jaringan epidermis, jaringan dasar, jaringan penguat (kolenkim dan sklerenkim), dan jaringan pengangkut. Sklerenkim dijumpai di bagian korteks dan di antara jaringan pengangkut. Organ berupa daun tersusun dari jaringan epidermis, palisade, dan bunga karang. Derivat epidermis yang dijumpai berupa stomata dan jenis trikoma berupa kapitat. Trikoma kapitat dijumpai di abaksial dan adaksial. Trikoma tersebut merupakan trikoma kelenjar yang diduga mengandung senyawa sebagai bahan obat.

\section{Ucapan Terima Kasih}

Ucapan terima kasih kepada Agus parada yang telah membantu dalam pengumpulan data, selain itu kepada Darius Rupa yang telah membantu saat pengumpulan data, analisis dan interpretasi data serta penyusunan naskah dan merevisi secara kritis untuk isi yang penting dalam naskah.

\section{Daftar Pustaka}

Allobua, N. 2018. Pengembangan Majalah Sins Berbasis Riset pada Tanaman Bawang Dayak (Eleutherine palmifolia (L.) Merr.) Sebagai Sumber Belajar Mandiri Bagi Siswa SMA/MA. Skripsi. Tarakan.

de Oliveira, A.B,de Mendonça, M.S., Azevedo, A.A., Meira, R.M.S. A.(2012). Anatomy and Histochemistry of The Vegetative Organs of Cissus Verticillata-a Native Medicinal 


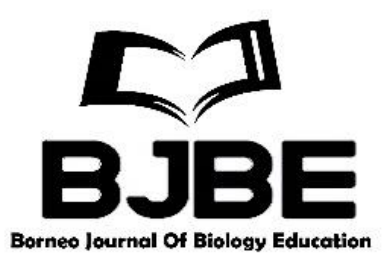

Plant of The Brazilian Amazon. Jurnal of Revista Brasileria de Farmacognosia. 22(6): 1201-1211. DOI: org/10.1590/S0102-695X2012005000053.

Namukobe, J., Kasenene, J.M., Kiremire, B.T., Byamukama, R., Mugisha, M.K., Krief, S., Dumontet, V., Kabasa, J.D. (2011). Traditional plants used for medicinal purposes by local communities around theNorthern sector of Kibale National Park, Uganda. Journal of Ethnopharmacology. 136: 236-245.

Prelina Munien, P., Naidoo, Y., Naidoo, G. (2015). Micromorphology, histochemistry and ultrastructure of the foliartrichomes of Withania somnifera (L.) Dunal (Solanaceae). Planta 242:1107-1122. DOI: 10.1007/s00425-015-2341-1.

Rupa, D. (2015).Identifikasi Struktur Sekretori dan Analisis Histokimia serta Fitokimia Tumbuhan Obat Anti-infeksi di Kawasan Taman Nasional Bukit Duabelas Jambi. [Tesis]. Institut Pertanian Bogor.

Rupa, D., Sulistyaningsih, Y. C., Dorly., Ratnadewi, D. (2017). Identification of Secretory Structure,Histochemistry and Phytochemical Compoundsof Medicinal Plant Hyptis capitata Jacq.BIOTROPIA-The Southeast Asian Journal of Tropical Biology, 24(2), 94103. DOI: $10.11598 / \mathrm{btb} .2017 .24 .2 .499$.

Rupa D.,Alfianur, Adhani, A., Zulfadli. (2017). Secretory structures, histochemical and phytochemical compounds in the physialis angulata leaves (solanaceae) as a prospect of medicinal development. International Journal of Advances in Science Engineering and Technology. 5(2): 56-61.

Rupa D., Alfianur, Adhani, A., Zulfadli. (2017). Secretory Structures, Histochemical and Phytochemical Compounds in the Physialis angulate Leaves (Solanaceae) as a Prospect of Medicinal Development. Proceedings of $79^{\text {th }}$ IASTEM International Conference, 6-7 October 2017. Tokyo, Japan.

Sass JE. 1951. Botanical Microtehnique. Iowa (US): Iowa State Coll Pr. 248 hlm.

Shah, V.V., Shah, N.D., Patrekar, P.V. (2013). Medicinal plants from Solanaceae family. Research J. Pharm. and Tech. 6(2): 143-151.

Suparman, A., Rupa, D., Zulfadli. (2017). Identification of secretory structure and histochemical of family Araceae as medicinal plants by Dayak Kenyah tribe. Applied Science and Technology. 1(2):26-30.

Suparman, A. 2018. Pengembangan Majalah Sains Berbasis Riset Berdasarkan Skrining Tumbuhan Obat dan Pemanfaatannya sebagai Sumber Belajar Mandiri bagi Siswa SMA/MA. Skripsi.Universitas Borneo Tarakan.

Umah, C., Dorly, Sulistyaningsih, Y.C. (2017). Secretory Structure, Histochemistry and Phytochemistry Analyses of Stimulant Plant. IOP Conf. Series: Earth and Environmental Science58(2017)012048. DOI:10.1088/1755-1315/58/1/012048.

Salurapa, A. (2018). Pengembangan Buku Referensi Berdasarkan Histokimia dan Uji Aktivitas Antibakteri dari Ekstrak Akar Polygala paniculata L. Terhadap Bakteri Patogen. Skripsi. Tarakan.

St-Pierre, B., Vazquez-Flota, De Luca, V. (1999). Multicellular Compartementation of Catharanthus roseus Alkaloid Biosynthesis Predicts Intercellular Translocation of a Pathway Intermediate. The Plant Cell. 11:887-900. 